\title{
MISCELLLANEA GEOGRAPHICA
}

Vol. 122006 pp. 67-73

\author{
Katarzyna Grabowska \\ Department of Climatology \\ E-mail: kasiaw@uw.edu.pl
}

\section{DANGEROUS WEATHER PHENOMENA IN EUROPE IN THE YEAR 2000 AND THEIR DEPENDENCE ON CIRCULATION}

\begin{abstract}
In the paper the influence of atmospheric circulation on selected dangerous weather phenomena in Europe in the year 2000 has been presented. Dangerous weather phenomena include: 30 days with thunderstorms in Poland and 26 examples of such phenomena in Europe (tornados, strong winds, thunderstorms, torrential rains, floods, etc.).

The NAO index (North Atlantic Oscillation) served to determine the character of the circulation that influenced the occurrence of catastrophic phenomena in Western, Central and Southern Europe. The J. Lityński classification of circulation types was used to thunderstorms occurring in Poland only. Most catastrophic phenomena during the positive NAO phase (predominance of zonal circulation) happened in Western and Central Europe. During the negative NAO phase (predominance of meridional circulation) the regions of the Mediterranean Basin were more frequently affected. In the case of thunderstorms in Poland in the year under investigation (2000) their occurrence was related to the inflow of air masses from the northern sector.
\end{abstract}

Key words: dangerous weather phenomena, thunderstorms, Europe, Poland, North Atlantic Oscillation NAO, Litynski types of atmospheric circulation.

\section{INTRODUCTION}

During the last 10-20 years extreme weather phenomena and the accompanying natural disasters have been happening more often not only in Europe but also in the whole world. They pose a serious threat for our lives; they paralyse the road, railway, air and sea transport, bring damage to the national economy and cause material destruction. The possibility of learning about and predicting dangerous weather phenomena- which is done based on atmospheric circulation, among other things- is therefore a very important issue.

The goal of the paper is the determination of connections of selected dangerous weather phenomena in Europe with the types of atmospheric circulation determined after the NAO (North Atlantic Oscillation) index and the J. Lityński classification (2000). 


\section{SOURCE MATERIAL AND RESEARCH METHODOLOGY}

Source material comes from the year 2000, both from the almanac of the most important events in Europe and from the meteorological observatory Warszawa-Okęcie in Poland.

Dangerous weather phenomena consist of: 30 days with thunderstorms in Poland and 26 selected examples of the most catastrophic phenomena in Europe. This includes: tornados, strong winds (hurricanes), thunderstorms, fires, snow storms, torrential rains and accompanying floods, as well as weather conditions resulting in avalanches, debris flows and mudslides in Europe.

The NAO index (daily and mean monthly NAO indices- the difference of the normalised pressure between Lisbon and Stykkisholmur in Iceland) was used to determine the circulation character influencing the occurrence of dangerous phenomena in Western, Central and Southern Europe (Marsz and Styszyńska 2001), (http://www.atmosphere.mpg.de/enid/658).

J. Lityński numeric classification was applied to thunderstorms occurring only in Central Europe, that is, in Poland.

Since the phenomena under investigation are very varied, they were divided according to the region of occurrence and assigned the appropriate circulation types (the NAO type to all and the Lityński type to Central Europe only). Since the North Atlantic Oscillations are more marked in the winter season, dangerous phenomena in the cold half-year (October-March) and in the warm half-year (April-September) were considered separately.

\section{RESULTS}

In the year 2000 in Warsaw there were 30 days with thunderstorms. Circulation types of cyclone character create the most favourable conditions for thunderstorms; they make up 43.4\% (13 days) of all cases (Tables 1 and 2 ). Somewhat fewer days with thunderstorms- $33.3 \%$ (10 days)- were related to the zero character type, that is, during the lack of marked air advection over Poland. The least favourable conditions for thunderstorms were created by types of anticyclone character, constituting $23.3 \%$ ( 7 days). During the analysis of the directions of inflow of air masses during the thunderstorm days, however, it turned out that more than half of thunderstorms- $66.7 \%$ (20 days)- occurred when the circulation type was from the western and northern sectors, in the direction from $\mathrm{SW}$ to NE; thunderstorms from the northern sector (NW-NE) constituted as many as $46.7 \%$ (14 days). Particularly favourable for thunderstorms in the year 2000 were the $\mathrm{N}_{\mathrm{C}}$ circulation- $16.7 \%$ (5 days), as well as $\mathrm{NE}_{\mathrm{C}}$ and $\mathrm{SW}_{0}-10 \%$ (3 days) each. $\mathrm{As}$ many as $23.3 \%$ ( 7 days) fell on the northern direction only. No thunderstorms occurred during the $\mathrm{W}_{\mathrm{C}}, \mathrm{NW}_{\mathrm{C}}, \mathrm{NE}_{0}, \mathrm{SE}_{0}, \mathrm{SE}_{\mathrm{A}}, \mathrm{S}_{\mathrm{A}}$ and $\mathrm{SW}_{\mathrm{A}}$ circulation.

When considering the influence of the North Atlantic Oscillation on the occurrence of thunderstorms days, however, it turned out that the positive 
Types of atmospheric circulation according to J. Lityński classification; daily and monthly values of the NAO index on individual days with thunderstorms in Warsaw in 2000

\begin{tabular}{|c|c|c|c|c|}
\hline $\begin{array}{c}\text { Day with } \\
\text { thunderstorm }\end{array}$ & $\begin{array}{c}\text { Influx } \\
\text { direction }\end{array}$ & $\begin{array}{c}\text { Circulation } \\
\text { character }\end{array}$ & NAO daily & NAO monthly \\
\hline 20.04 & $E$ & 0 & -0.285 & 0.0 \\
\hline 21.04 & 0 & $\mathrm{~A}$ & -0.095 & 0.0 \\
\hline 26.04 & $\mathrm{~S}$ & 0 & 0.473 & 0.0 \\
\hline 18.05 & SW & $\mathrm{C}$ & 1.940 & 1.6 \\
\hline 28.05 & $\mathrm{SW}$ & 0 & 0.302 & 1.6 \\
\hline 30.05 & NW & 0 & 0.602 & 1.6 \\
\hline 06.06 & $\mathrm{NE}$ & $\mathrm{C}$ & 1.073 & 0.0 \\
\hline 14.06 & NW & $\mathrm{A}$ & 0.294 & 0.0 \\
\hline 17.06 & $\mathrm{NE}$ & $\mathrm{A}$ & -0.148 & 0.0 \\
\hline 22.06 & SW & 0 & -1.547 & 0.0 \\
\hline 04.07 & 0 & $\mathrm{C}$ & -1.839 & -1.0 \\
\hline 05.07 & $\mathrm{~N}$ & $\mathrm{C}$ & -1.070 & -1.0 \\
\hline 16.07 & $\mathrm{NE}$ & $\mathrm{C}$ & 1.812 & -1.0 \\
\hline 17.07 & $\mathrm{~N}$ & $\mathrm{C}$ & 2.116 & -1.0 \\
\hline 23.07 & $\mathrm{E}$ & $\mathrm{A}$ & 0.270 & -1.0 \\
\hline 25.07 & $\mathrm{SE}$ & $\mathrm{C}$ & -2.961 & -1.0 \\
\hline 29.07 & $\mathrm{~N}$ & $\mathrm{C}$ & -2.406 & -1.0 \\
\hline 2.08 & W & $\mathrm{A}$ & 0.133 & -0.3 \\
\hline 5.08 & $\mathrm{~N}$ & $\mathrm{~A}$ & 0.000 & -0.3 \\
\hline 11.08 & 0 & 0 & 0.261 & -0.3 \\
\hline 17.08 & $\mathrm{~W}$ & 0 & -1.431 & -0.3 \\
\hline 19.08 & SW & 0 & -1.303 & -0.3 \\
\hline 20.08 & 0 & 0 & -1.141 & -0.3 \\
\hline 22.08 & $\mathrm{~N}$ & 0 & -0.065 & -0.3 \\
\hline 23.08 & NW & $\mathrm{A}$ & 0.653 & -0.3 \\
\hline 31.08 & $\mathrm{~S}$ & $\mathrm{C}$ & 0.197 & -0.3 \\
\hline 2.09 & $\mathrm{~N}$ & $\mathrm{C}$ & -0.691 & -0.2 \\
\hline 3.09 & $\mathrm{~N}$ & C & -0.987 & -0.2 \\
\hline 4.09 & $\mathrm{NE}$ & $\mathrm{C}$ & -1.021 & -0.2 \\
\hline 13.09 & $\mathrm{E}$ & $\mathrm{C}$ & 0.730 & -0.2 \\
\hline
\end{tabular}

Table 2 . Number of days with thunderstorms in individual types of atmospheric circulation according to J. Lityński classification in Warsaw in 2000

\begin{tabular}{|l|c|c|c|c|c|c|c|c|c|c|c|}
\hline & N & NE & E & SE & S & SW & W & NW & 0 & Sum & $\%$ \\
\hline C & 5 & 3 & 1 & 1 & 1 & 1 & - & - & 1 & 13 & 43.4 \\
\hline 0 & 1 & - & 1 & - & 1 & 3 & 1 & 1 & 2 & 10 & 33.3 \\
\hline A & 1 & 1 & 1 & - & - & - & 1 & 2 & 1 & 7 & 23.3 \\
\hline Sum & 7 & 4 & 3 & 1 & 2 & 4 & 2 & 3 & 4 & 30 & 100.0 \\
\hline$\%$ & 23.3 & 13.3 & 10.0 & 3.4 & 6.7 & 13.3 & 6.7 & 10.0 & 13.3 & 100.0 & \\
\hline
\end{tabular}


Table 3.

Daily and monthly values of the NAO index on selected days with catastrophic phenomena in Europe in 2000

\begin{tabular}{|c|c|c|c|}
\hline Catastrophic phenomena & $\begin{array}{c}\text { Date } \\
(2000)\end{array}$ & $\begin{array}{l}\text { NAO } \\
\text { daily }\end{array}$ & $\begin{array}{c}\text { NAO } \\
\text { monthly }\end{array}$ \\
\hline $\begin{array}{l}\text { In Germany strong wind with gusts up to } 160 \mathrm{~km} / \mathrm{h} \text {, four } \\
\text { people died. On the North Sea and Baltic Sea coasts } \\
\text { storm wave flooded the streets of many harbour cities. }\end{array}$ & 29.01 & 0.719 & 0.6 \\
\hline $\begin{array}{l}\text { Avalanches in the Alps: in the town of Val di Mazia in } \\
\text { the Italian region of Upper Adige near the border with } \\
\text { Austria, near Davos in eastern Switzerland. Six people } \\
\text { died, including three skiers. }\end{array}$ & 21.02 & 1.080 & 1.7 \\
\hline $\begin{array}{l}\text { Torrential rains and hurricanes affected western Ukraine. } \\
\text { Power outage in } 694 \text { towns. }\end{array}$ & 5.07 & -1.070 & -1.0 \\
\hline $\begin{array}{l}\text { In Switzerland a mudslide fell on the trail to the Grosse } \\
\text { Scheidegg Mountain. Three people died (tourists). }\end{array}$ & 6.08 & -0.494 & -0.3 \\
\hline $\begin{array}{l}\text { Violent storms with very strong winds passed over south- } \\
\text { eastern France: Marseille and Montpellier. These were } \\
\text { the strongest thunderstorms in this region in the last } \\
100 \text { years. Six people died. }\end{array}$ & 19.09 & -0.428 & -0.2 \\
\hline $\begin{array}{l}\text { South England was hit by powerful winds and rains. } \\
\text { The greatest damage was in the counties of Kent and } \\
\text { eastern and western Sussex, from where most inhabit- } \\
\text { ants were evacuated. Floods flooded houses and roads. }\end{array}$ & 12.10 & $\begin{array}{l}-1.037 \\
-0.031\end{array}$ & 0.9 \\
\hline $\begin{array}{l}\text { Violent flood affected the Swiss-Italian border region and } \\
\text { the South-west of France; } 20 \text { people died. In the Swiss } \\
\text { Alps, on the border with Italy, landslides destroyed } 1 / 3 \\
\text { of the village of Gondo. Due to floods and landslides } \\
\text { many roads in the Alps and in southwestern France } \\
\text { were impassable, and the Italian Aosta Valley became } \\
\text { entirely cut off from the world. In Piedmont, suburbs } \\
\text { of Turin and Padua were flooded with water. Waters in } \\
\text { Lago Maggiore reached the record high of } 197.26 \mathrm{~cm} \text {, } \\
\text { flooding part of the town of Locarno. Floods affected also } \\
\text { other towns located on the coast of the lake. Part of the } \\
\text { Magadino plain was flooded. }\end{array}$ & $\begin{array}{l}14.10 \\
15.10 \\
16.10\end{array}$ & $\begin{array}{l}0.968 \\
0.717 \\
0.559\end{array}$ & $\begin{array}{l}0.9 \\
0.9 \\
0.9\end{array}$ \\
\hline $\begin{array}{l}\text { Fire in Slovakia near Hrabušice, on the northern out. } \\
\text { skirts of the National Park Slovak Paradise destroyed } \\
62 \text { ha of forests. Six people died as a result of the fire. }\end{array}$ & $\begin{array}{l}23.10 \\
24.10 \\
25.10 \\
26.10 \\
27.10 \\
28.10\end{array}$ & $\begin{array}{l}1.220 \\
1.794 \\
1.608 \\
1.301 \\
0.935 \\
0.150\end{array}$ & $\begin{array}{l}0.9 \\
0.9 \\
0.9 \\
0.9 \\
0.9 \\
0.9\end{array}$ \\
\hline $\begin{array}{l}\text { On the east coast of Spain a catastrophic flood occurred. } \\
\text { Water level in the Ebro River rose by } 2.5 \mathrm{~m} \text {. In towns } \\
\text { of the region of the Ebro river delta about one thousand } \\
\text { apartments were affected by power outage. Entire towns } \\
\text { were flooded, roads cut off, including a few highways. } \\
\text { Five people died. }\end{array}$ & 24.10 & 1.794 & 0.9 \\
\hline $\begin{array}{l}\text { A tornado passed over the English coastal town of Bognor } \\
\text { Regis. Four people were injured and hundreds of houses } \\
\text { were damaged. }\end{array}$ & $\begin{array}{l}28.10 \\
29.10\end{array}$ & $\begin{array}{r}0.150 \\
-0.180\end{array}$ & $\begin{array}{l}0.9 \\
0.9\end{array}$ \\
\hline
\end{tabular}




\begin{tabular}{|c|c|c|c|}
\hline $\begin{array}{l}\text { Strong winds in a few European countries caused the } \\
\text { death of eight people. In Great Britain five people died; } \\
\text { in France, three. A gale in southern England and Wales, } \\
\text { with gusts up to } 140 \mathrm{~km} / \mathrm{h} \text {, caused power outage in thou- } \\
\text { sands of houses; many streets were flooded. In Germany } \\
\text { and France wind, in gusts until } 180 \mathrm{~km} / \mathrm{h} \text {, paralysed the } \\
\text { entire transportation in some regions. }\end{array}$ & 30.10 & -0.539 & 0.8 \\
\hline \multirow{3}{*}{$\begin{array}{l}\text { Torrential rains and winds in Great Britain caused the } \\
\text { death of two people. Over } 3000 \text { inhabitants of York, af- } \\
\text { fected by the flood, were evacuated. Water in the river } \\
\text { reached there the highest level since } 1625 \text {, flooding over } \\
\text { one thousand houses. }\end{array}$} & 3.11 & -1.070 & -0.9 \\
\hline & 4.11 & -1.304 & -0.9 \\
\hline & 5.11 & -2.010 & -0.9 \\
\hline $\begin{array}{l}\text { A rock avalanche fell on cars driving on the road Podgo- } \\
\text { rica-Kolashin in Montenegro. At least eight people were } \\
\text { killed. }\end{array}$ & 5.11 & -2.010 & -0.9 \\
\hline $\begin{array}{l}\text { A mudslide and rock avalanche descended on alpine } \\
\text { villages in northwestern Slovenia. One person died and } \\
\text { six were missing. It destroyed five houses and the road } \\
\text { in the village. In the region of Triglav Mountain rains } \\
\text { persisted for over two weeks and on the slopes debris } \\
\text { and mudflows were formed. }\end{array}$ & 17.11 & $\cdot 2.327$ & -0.9 \\
\hline $\begin{array}{l}\text { Torrential rains lasting three days caused the sliding } \\
\text { of wet earth near Lucca in central Italy. Five people } \\
\text { carried away by the sliding earth were missing. }\end{array}$ & 20.11 & -3.602 & -0.9 \\
\hline $\begin{array}{l}\text { Heavy rains occurred in southwestern England and } \\
\text { Wales; two people died. }\end{array}$ & 8.12 & -0.278 & -0.6 \\
\hline $\begin{array}{l}\text { Rains and thunderstorms, the most powerful in } 130 \\
\text { years, hit Galicia in northwestern Spain. Four people } \\
\text { died. About } 70 \text { thousand people were without power for } \\
\text { many hours (strong wind damaged power lines). Water } \\
\text { flooded two highways, one fast lane and over } 30 \text { local } \\
\text { roads. Railway connecting this province with Madrid } \\
\text { and Barcelona was also cut off. Over one thousand peo- } \\
\text { ple were evacuated. In Lugo a fragment of an ancient } \\
\text { Roman wall, included in the UNESCO World Heritage } \\
\text { List in 2000, fell. }\end{array}$ & 8.12 & -0.278 & -0.6 \\
\hline $\begin{array}{l}\text { Torrential rains occurred near Salerno in southern } \\
\text { Italy. About } 500 \text { people were evacuated due to the risk } \\
\text { of mudslides. During one day the precipitation was al- } \\
\text { most } 170 \mathrm{~mm} \text {. In central Italy the Aniene River near the } \\
\text { Hadrian Villa in the well-known tourist centre Tivoli } \\
\text { flooded; several tens of people were evacuated. }\end{array}$ & 28.12 & -0.920 & -0.6 \\
\hline $\begin{array}{l}\text { Snowstorms and strong winds occurred in northern and } \\
\text { eastern Spain. Winds had the speed of } 90 \mathrm{~km} / \mathrm{h} \text {, felled } \\
\text { trees and destroyed some houses, mostly in eastern } \\
\text { Spain. In the north of the country snow blocked nine } \\
\text { large mountain passes. }\end{array}$ & 30.12 & -0.432 & -0.6 \\
\hline
\end{tabular}

Source: Kalendarium najważniejszych wydarzeń w Europie. Encyklopedia Geograficzna Swiata, Suplement [Almanac of the Most Important Events in Europe. Geographical Encyclopaedia of the World, Supplement; in Polish], pp. 146-157, selection (Kurek, 2001). 
Table 4.

Positive and negative NAO phases (daily and monthly) on selected days with dangerous phenomena in the cold and warm half-years in Europe in 2000

\begin{tabular}{|c|c|c|c|}
\hline \multicolumn{2}{|c|}{ Dates of dangerous phenomena in 2000} & \multicolumn{2}{|c|}{ Positive or negative NAO phase } \\
\hline Month & Day & Daily NAO & Monthly NAO \\
\hline \multicolumn{4}{|c|}{ Cold half-year } \\
\hline January & 29 & + & + \\
\hline February & 21 & + & + \\
\hline \multirow{2}{*}{ October } & $14,15,16,23,24,25,26,27,28$ & + & \multirow[t]{2}{*}{+} \\
\hline & $11,12,29,30$ & - & \\
\hline November & $3,4,5,17,20$ & - & - \\
\hline December & $8,28,30$ & - & - \\
\hline \multicolumn{4}{|c|}{ Warm half-year } \\
\hline July & 5 & - & - \\
\hline August & 6 & - & - \\
\hline September & 19 & $\cdot$ & - \\
\hline
\end{tabular}

NAO phase influences one half of the cases (15 days or $50 \%$ ) and the negative phase, another half. Although the positive phase related to the zonal circulation over Europe alternated with the negative phase with predominant meridional circulation, longer periods of thunderstorms during the "+"NAO occurred more often in spring and the first half of summer (from 26 April through 11 August)- 12 days with thunderstorms. During the-"NAO phase more thunderstorm days occurred during the second half of summer (from 25 July through 4 September)- 9 days. The mean monthly values of NAO indicate that the positive and zero phases occurred in April, May and June (even though spring and early summer should be cloudy and cooler, heat waves occurred then as well), while the negative phase occurred in July, August and September (bringing with it a very hot summer with a large number of days with thunderstorms).

From the analysed year 2000 twenty-six days were selected in which catastrophic phenomena causing serious damages in various regions of Europe, often including fatalities, occurred (Table 3). The issue of the most favourable NAO phase for the dangerous weather phenomena was investigated.

North American Oscillations are usually more strongly marked in the winter season; for that reason dangerous phenomena in the cold half-year (October-March) and the warm half-year (April-September) were considered separately.

During the warm half-year only three days (5 July, 6 August and 19 September) with dangerous phenomena occurred, constituting only $11.5 \%$ of all cases; all of them happened during the negative NAO phase (both as regards the daily and monthly values in July, August and September of the year 2000) (Table 4).

During the cold half-year, on the other hand, catastrophic phenomena were frequent and constituted as much as $88.5 \%$ of all events. During this 
period the positive NAO phase occurred in winter on 29 January and 21 February and during nine days from 14 through 28 October, which together constitutes $47.8 \%$ (11 days). The negative NAO phase occurred not much more frequently - in $52.5 \%$ cases in the cold half-year (12 days): in the early autumn, on 11-12 October and during ten days in autumn and early winter form 29 October through 30 December. Mean monthly NAO values in January, February and October are positive, while in the other two months under investigation (November and December), negative.

\section{CONCLUSIONS}

It is worth noting that most of the catastrophic events occurring during the positive NAO phase (when zone circulation predominates) occurred in Western and Central Europe, in particular in Germany and Slovakia, in the Swiss and Italian Alps, in southwest of France and in England. During the negative NAO phase (the predominance of meridional circulation) the regions of the Mediterranean Basin, from Spain through southeastern France, Italy, Switzerland, Slovenia and Montenegro and as far as western Ukraine were more affected. Of course, disasters occurred during that period also in England, France and Germany, but less frequently.

Summarising, one can state that thunderstorms in Poland and Europe can occur during each NAO phase, similarly to other dangerous phenomena in Northern and Central Europe. In Southern Europe, however, dangerous phenomena occur more frequently during the negative NAO phase, when the weather conditions are influenced by the meridional circulation.

In the case of thunderstorms in Poland in the year under investigation (2000), circulation types of cyclone character (related to the movement of atmospheric lows and fronts) were more dangerous. The occurrence of thunderstorms was related mostly to the inflow of air masses from the northern sector.

\section{REFERENCES}

Kurek S., 2001, Kalendarium najważniejszych wydarzeń (Europa). Encyklopedia Geograficzna Świata, Suplement [Almanac of the Most Im portant Events (Europe). Geographical Encyclopaedia of the World. Supplement; in Polish], Kraków, Agencja PublicystycznoWydawnicza "Opres".

Kalendarz typów cyrkulacji atmosferycznej w 2000 roku wedtug J. Lityńskiego [Calendar of the Types of Atmospheric Circulation in 2000 according to J. Lityński; in Polish]. Warszawa, IMGW.

Marsz A., S ty s z ýn s a A., 2001, Oscylacja Pótnocnego Atlantyku a tem peratura powietrza nad Polskq [North Atlantic Oscillation and Air Temperature Over Poland; in Polish], Gdynia, Wyd. Uczelniane Wyższej Szkoły Morskiej.

http://www.atmosphere.mpg.de/enid/658

English translation: Malgorzata Mikulska 